\title{
平板と波板からなる乾式組立鋼製床の重量床衝撃音遮断性の評価 EVALUATION OF IMPACT SOUND INSULATION PERFORMANCE OF DRYLY BUILT-UP STEEL FLOOR MADE OF FLAT AND CORRUGATED PLATES
}

\author{
中安誠明*1, 半谷公司*2, 菅野良一 ${ }^{* 3}$, 高橋大弐*4 \\ Nariaki NAKAYASU, Koji HANYA, Ryoichi KANNO \\ and Daiji TAKAHASHI
}

\begin{abstract}
Steel structures have merits such as light weight and short period of construction. Aiming at realization of such a steel floor, scaled model test and full-scale test have been carried out in order to evaluate the impact sound insulation performance of steel floor using flat and corrugated plates. Test results indicate, 1) the correction of sound level of steel floor in scale model test is effective by following the difference of impact force characteristics between scaled model test and full-scale test, 2) steel floor made of flat and corrugate plates tends to have anisotropy in bending stiffness and sound insulation performance of the floor can be improved by increasing the bending stiffness around weak axis, for example by narrowing the width of flange of corrugated steel plate, and 3) local vibration of lower flat plate may worsen the insulation performance of steel floor but its frequency can be designed in the higher range so that the decreasing of sound level is relatively easier.
\end{abstract}

Keywords: Dryly built-up Steel Floor, Floor Impact Sound, 1/4 Scale Model Test, Vibration Eigen value Analysis 乾式組立鋼製床，重量床衝撃音，1/4 縮小模型実験，振動固有值解析

\section{1. はじめに}

わが国の鋼構造建築物の柱や梁、筋かい、屋根、壁などにおいて は各種の鋼製部材が開発されてきており、実物件においてもそれら が単独で、場合によってはコンクリートなどの異種材と併せた合成 部材として一般的に用いられている。一方、床においては、型枠用 や合成構造用のデッキプレートとして、波形などに加工された薄鋼 板がコンクリートと併用される場合はあるものの、単独で用いられ るような鋼製部材は一般的な技術としてはなく、依然として現場生 産のコンクリートが用いられるのが主流である 1)、2)など。

鋼構造の長所として、比強度が大きいことにより大スパン構造を 実現できる点や、工場生産により工期を短縮でき、品質を一定に保 つことができる点、乾式接合も用いられ材料がリサイクル可能なこ とによって使用後の解体性が高い点などが挙げられる。しかしなが ら、現状の鋼構造建築物において、柱や梁などには鋼製部材が積極 的に使用されているが、床には現場生産のコンクリートが用いられ ていることを踏まえると、この床のコンクリートが原因となり、鋼 構造の長所が十分に発揮されていない可能性があるとも考えられる。

これに対し、鋼構造の長所の更なる促進を狙い、建築床の軽量化 や、工期の短縮、解体性の向上などを目指して、各種の新構工法の 提案も行われている。コンクリート系の材料を用いる案として、例 えば文献 3)や 4)では、床の軽量化を目指し、比重 1.4 の軽量コンク リートを用いる床や、平鋼板と軽量気泡コンクリートからなるサン
ドイッチ床版が示され、文献 5～7)では、解体性の向上を目指し、 梁からの着脱が可能な床が示されている。また、鋼材を積極的に用 いる案として、文献 8)では、床の軽量化を目指し、平鋼板と無発泡 ウレタンを用いるパネルや、文献 9)や 10)では、軽量化と工期の短 縮を目指し、木質系面材等と波形に加工した鋼板からなるサンドイ ッチ床版が示されている。更には、床を鋼材のみで形成する案もあ り、文献 11)や 12)では、軽量化を目指し、平鋼板や形鋼と波形に加 工した鋼板からなるサンドイッチパネルが示されている。なお、一 連の案において、鋼材の使用比率の高い後者のものほど、鋼構造の 長所を多く享受できる可能性があるといえる。

各種の新構工法が提案される一方で、実物件においては依然とし て現場生産のコンクリート床が多用される理由の一つとして、建築 床に求められる性能が多様であり、実機適用に際して必要とされる それらの評価がいまだ十分になされていない点があると考えられる。 例えば文献 2)や 13)〜 15)などを参照すると、建築床に求められる性 能は 3 種類の技術分野に関わるものとして整理され、それらは、耐 静荷重性や耐震性、耐火性などを含む構造性、精度や工期などを含 む施工性、および遮音性や不振動性、耐熱性などを含む環境性とな るが、文献 3)〜12)での性能評価は、構造性や施工性の評価にとど まっているものが大半で、環境性にまで踏み込んでいるものはほと んど見られない。

そこで本論では、鋼構造の長所の更なる促進を狙い、現場生産の
*1 新日鐵住金技術開発本部鋼構造研究部 主任研究員·工修

$* 2$ 新日鐵住金技術開発本部鋼構造研究部主幹研究員・工博

*3 新日鐵住金技術開発本部 フェロー・Ph. D.

*4 京都大学大学院工学研究科建築学専攻 教授. 工博
Researcher, Nippon Steel \& Sumitomo Metal Corporation, M. Eng. Senior Researcher, Nippon Steel \& Sumitomo Metal Corporation, Dr. Eng.

Fellow, Nippon Steel \& Sumitomo Metal Corporation, Ph. D.

Prof., Dept. of Architecture and Architectural Engineering, Kyoto University, Dr. Eng. 

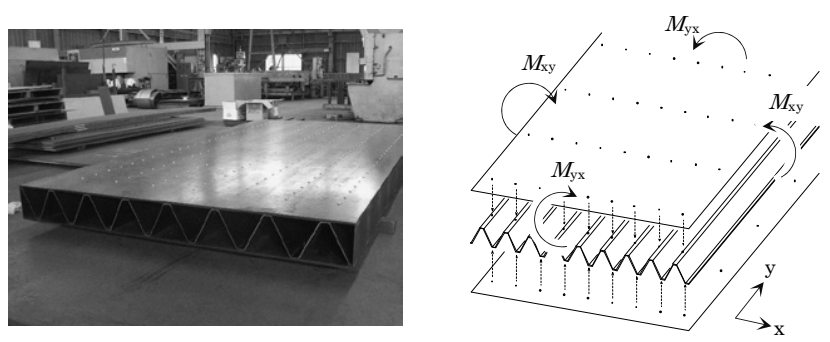

図 1 乾式組立鋼製床

コンクリート床に代わって適用可能な鋼製部材の将来的な具現化を 目指し、その端緒として、床用鋼製部材の環境性の評価に取り組む。 対象の床としては、文献 12)を参考に、鋼構造の長所の促進を最大 化できると考える鋼材のみで構成されるものとし、平板と波形の鋼 板をドリルねじ 16) 18)などで接合するサンドイッチパネルを想定する。 本論では、これを乾式組立鋼製床と称する。また、環境性の評価項 目は遮音性とし、その中でも重量床衝撃音に注目することとする。 これは環境性のうち、居住者による住環境の質の評価においては音 環境の及ぼす影響が大きいこと ${ }^{19)}$ 、および床に必要な遮音性として は重量床衝撃音や、軽量床衝撃音、界床の透過音の遮断性などがあ るが 20)、軽量床衝撃音と透過音はカーペットや天井といった仕上材 による対策が可能である一方、重量床衝撃音は床の躯体を含めた対 策が必要でとなることから ${ }^{21)}$ 、乾式組立鋼製床にはコンクリート系 の床とは異なる固有の対策が必要になると考えることによる。以下 では、模型実験を主に用いた乾式組立鋼製床の重量床衝撃音の実験 結果と考察について報告する。

\section{2. 乾式組立鋼製床の概要}

図 1 に、本論で想定する乾式組立鋼製床を示す。上下面材に平鋼 板、芯材に波形に加工した鋼板を用いるサンドイッチパネルとし、 上下面材と芯材の鋼板は、ドリルねじによって接合する。芯材に波 形の部材を用いる理由は、床断面内に上下面材と芯材によるトラス が形成され、図 1 に示す $\mathrm{x}$ 軸回りの曲げに対してだけでなく、y 軸 回りの曲げに対してもサンドイッチパネルの効果が得られ、上下面 材と芯材の 3 枚の板からなる重亦板としてよりも大きな曲げ剛性の 発現が期待できるためである。次章以降、この平板と波板からなる 乾式組立鋼製床を対象とした検討を行う。

\section{3. 実験計画}

\section{1. 模型則比}

本論では、試験工期やコストの短縮といった利点を期待し、重量 床衝撃音特性の評価にあたっては模型実験を主に用いることとする。 文献 22)などを参考に、本論における模型実験の模型則比を表 1 、お よび以下に示す次第で設定する。まず、基礎模型則比として、実大 実験に対する長さを $1 / \mathrm{n}$ 、時間を $1 / \mathrm{n}$ 、比重 $\rho$ は同等と設定する（式 (1))。次に、これらを用い、誘導模型則比として、速度や加速度、 質量、衝撃力といった物理量を式(2)〜 (5)などにより設定する。なお、 本論の模型実験においては、既往の文献を参考に、 $\mathrm{n}=4$ と設定す る。これは、試験体や治具の製作や施工の観点から模型実験の長所 が得られやすい寸法であること、および実大床衝撃音の計測に適用 される時間重み特性が F (125ms) であることを踏まえ、各種現行 機器が標準的な仕様として有する Impulse $(35 \mathrm{~ms})$ をその $1 / 4$ 相当
として用いることで計測が比較的容易となるスケールを選択したこ とによる。

$$
\begin{aligned}
& x_{\mathrm{M}} / x_{\mathrm{R}}=1 / \mathrm{n}, t_{\mathrm{M}} / t_{\mathrm{R}}=1 / \mathrm{n}, \rho_{\mathrm{M}} / \rho_{\mathrm{R}}=1 \\
& V_{\mathrm{M}} / v_{\mathrm{R}}=\left\{\left(x_{\mathrm{M}}-x_{0, \mathrm{M}}\right) / t_{\mathrm{M}}\right\} /\left\{\left(x_{\mathrm{R}}-x_{0, \mathrm{R}}\right) / t_{\mathrm{R}}\right\}=1 \\
& \alpha_{\mathrm{M}} / \alpha_{\mathrm{R}}=\left\{\left(v_{\mathrm{M}}-v_{0, \mathrm{M}}\right) / t_{\mathrm{M}}\right\} /\left\{\left(v_{\mathrm{R}}-v_{0, \mathrm{R}}\right) / t_{\mathrm{R}}\right\}=\mathrm{n} \\
& m_{\mathrm{M}} / m_{\mathrm{R}}=\left(\rho_{\mathrm{M}} \cdot \boldsymbol{x}_{\mathrm{M}}{ }^{3}\right) /\left(\rho_{\mathrm{R}} \cdot x_{\mathrm{R}}{ }^{3}\right)=1 / \mathrm{n}^{3} \\
& F_{\mathrm{M}} / F_{\mathrm{R}}=\left(m_{\mathrm{M}} \cdot \alpha_{\mathrm{M}}\right) /\left(m_{\mathrm{R}} \cdot \alpha_{\mathrm{R}}\right)=1 / \mathrm{n}^{2}
\end{aligned}
$$

ここで、Iは長さ、 $t$ は時間、 $x_{0}$ は基準時間における変位、 $x$ は基 準時間から $t$ 秒後における変位、 $v_{0}$ は基準時間における速度、 $V$ は 基準時間から $t$ 秒後における速度、 $\alpha$ は加速度、 $m$ は質量、 $F$ は衝 撃力を示す。また、添え字の $\mathrm{M}$ は模型スケール、 $\mathrm{R}$ は実大スケール の変数を示す。

表 1 から、本論の模型則比に従えば、模型実験で計測される音圧 は実大実験と同等となることがわかる。

\section{2. 実験方法}

実大実験では、衝撃源として標準重量衝撃源（タイヤ）を用い、

\section{表 1 模型則比}

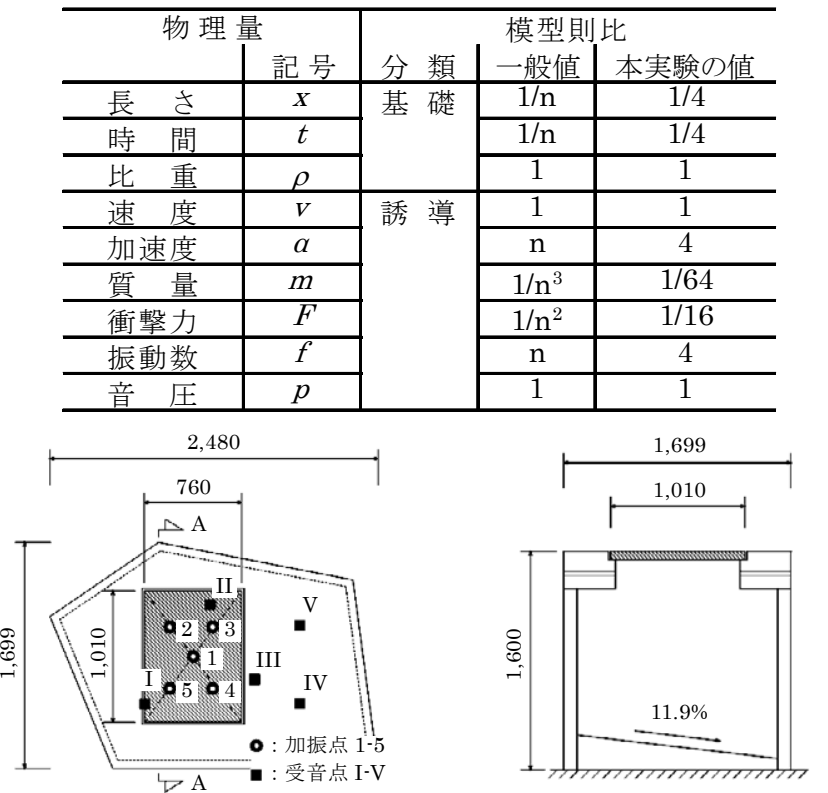

(a) 平面図

(b) A-A 断面図

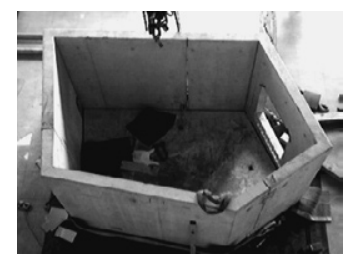

(c) 組立時の外観

図 2 模型残響室

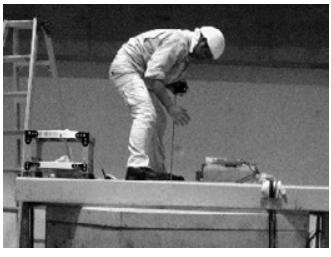

(a) 床上での加振の様子

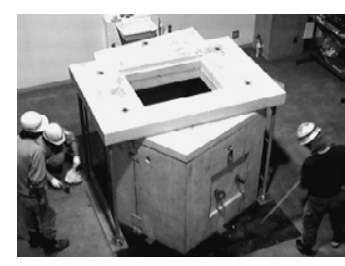

(d) 完成後の外観

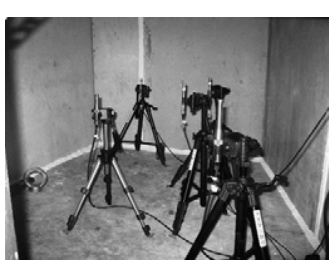

(b) 床下での計測の様子
図 3 模型実験の様子 
残響室としては財団法人建材試験センターの不整形七面体の設備を 用いる。床の中央 1 点と対角線の 4 等分点 4 点の計 5 点を加振点と し、残響室内の 5 点を受音点として、JIS A 1419-2 に準拠して重量 床衝撃音の評価を行う。

図 2 に、模型残響室の外観を加振点や受音点などの情報とあわせ て示す。また図 3 に、床上での加振の様子と床下での計測の様子を 示す。模型実験においては、衝撃源として軟式 A 球を用い 23)、直径 $72 \mathrm{~mm}$ 、質量 $135 \mathrm{~g}$ のものを高さ $500 \mathrm{~mm}$ から自由落下させる。こ こで、落下高さは、床表面からボールの中心までの距離として設定 している。残響室としては、財団法人建材試験センターの不整形七 面体を $1 / 4$ 縮小で再現したものを用いる。模型残響室においては、 実大実験の残響室と同様に、床試験体を載せ掛ける部分の振動が残 響室内の音圧に影響を及ぼすことを避けるため、同載せ掛け部分は、 残響室から高さ方向に $20 \mathrm{~mm}$ のクリアランスを設けて残響室から 独立した部材により支持して、クリアランスには硬質の発泡ウレタ ンフォームを設置している。重量床衝撃音の評価も実大実験と同様 とし、床中央 1 点と対角線の 4 等分点 4 点を含む計 5 点を加振して、 残響室内 5 箇所に設置した騒音計により、1/3 オクターブバンドと オクターブバンドごとの音圧レベルを計測し、受音点 5 点の計測值 をエネルギー平均して、かつ加振点 5 点の計測值を算術平均するこ ととする。騒音計の動特性は時間重み特性 F (125ms) の $1 / 4$ 相当 として Impulse（35ms）と設定する。

\section{3. 衝撃力特性の補正}

図 4 に、模型実験で用いる軟式 $\mathrm{A}$ 球の衝撃力特性を、実大実験に 用いる標準重量衝撃源（タイヤ）と比較して示す。衝撃力特性の計 測は、リオン株式会社社製の衝撃力測定装置 PF-10 用いて実施し ている。同図(a) は時刻歴特性、(b)は周波数特性の比較を示し、図(a) の縦軸は衝撃力、横軸は時間、図(b)の縦軸は衝撃力、横軸は周波数 を示す。軟式 A 球の值は、実大相当の值として、計測值に対して時 間を 4 倍、周波数を $1 / 4$ 倍、衝撃力を 16 倍した值として示す。

図 4(a)から、軟式 A 球の特徴として、衝撃力の継続時間内に、 $0.002 \mathrm{~s}$ 未満程度の周期の短い成分を含んでいることがわかる。また、 図 4(b)から、軟式 A 球は、標準重量衝撃源（タイヤ）と比較して、 $100 \mathrm{~Hz}$ 以下の周波数範囲においては衝撃力が小さいのに対し、同周 波数以上の範囲では衝撃力が大きくなっていることがわかる。これ は、軟式 A 球が有する表面の仕上げ形状が衝撃力の時刻歴特性に影 響を及ぼしているためと推察する。

そこで、本論における模型実験では、文献 24)にならい、衝撃力 の差異に応じて衝撃音の計測結果を補正することとする。表 2 に、 軟式 A 球と標準重量衝撃源（タイヤ）の衝撃力のレベル差を $1 / 3$ オ クターブバンド中心周波数とオクターブバンド中心周波数ごとに整 理したものを示す。同表中の值は、標準重量衝撃源（タイヤ）と軟 式 $\mathrm{A}$ 球の衝撃力の時刻歴の計測結果を用いて、 $1 \mathrm{~N}$ を基準の力とし て算定した衝撃力のレベルについて、実大相当の周波数帯域におけ る両者の差異として算出している。表中において、值が正である周 波数帯域において、軟式 A 球の衝撃力レベルが標準重量衝撃源（夕 イヤ）よりも大きい傾向であることを示す。本論の模型実験では、 この值を用いて補正した值を実験結果とし、評価の対象とする。

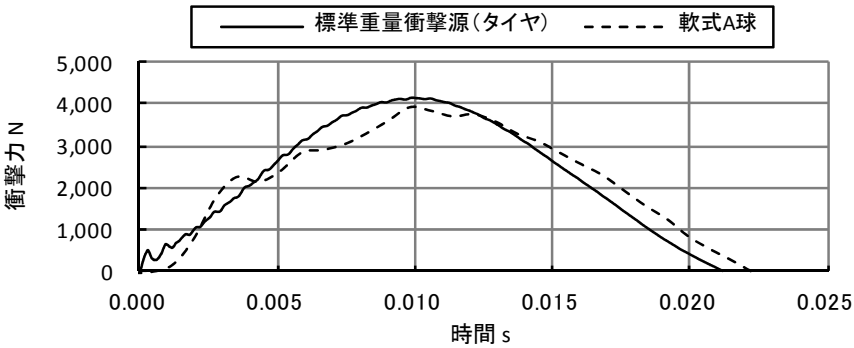

(a) 時刻歴特性

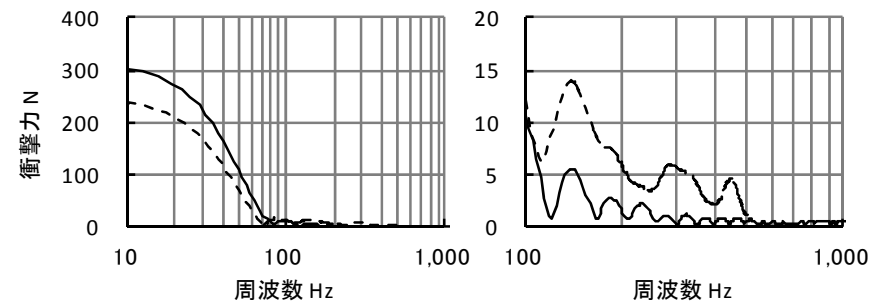

(b) 周波数特性（左：10～、右 $100 \sim 1,000 \mathrm{~Hz}$ )

図 4 衝撃源の衝撃力特性の比較

表 2 標準重量衝撃源（タイヤ）と軟式 A 球の衝撃カのレベル差

(a) 1/3オクターブバンド中心周波数の場合

\begin{tabular}{l|c|c|c|c|c|c|c|c|c|c|c|c}
\hline & \multicolumn{8}{|c}{$1 / 3$ オクター゙バンド中心周波数(実大相当) $\mathrm{Hz}$} \\
& 50 & 63 & 80 & 100 & 125 & 160 & 200 & 250 & 315 & 400 & 500 & 630 \\
\hline 差 $\mathrm{dB}$ & -1.9 & -4.8 & 3.2 & 4.7 & 12.8 & 13.7 & 14.8 & 14.6 & 19.2 & 16.0 & 13.0 & 1.6 \\
\hline
\end{tabular}

(b) オクターブバンド中心周波数の場合

\begin{tabular}{c|c|c|c|c}
\hline & \multicolumn{4}{|c}{ オクターブバンド中心周波数（実大相当） $\mathrm{Hz}$} \\
& 63 & 125 & 250 & 500 \\
\hline 差 $\mathrm{dB}$ & -2.0 & 9.1 & 16.1 & 14.5 \\
\hline
\end{tabular}

\section{4. 試験体}

表 3 に、試験体の一覧を示す。試験体は、模型実験との比較用の 実大試験体 1 種、および模型試験体 6 種とする。図 5 の模式図に、 表 3 中に記載する床試験体の長さ、幅、厚さ、上下面材厚さ、芯材 厚さ、ねじピッチ芯材フランジ幅、および芯材 1 ユニットの幅とい った各部の寸法の定義を示す。模型実験における寸法などは、製造 可能な範囲で、実大の乾式組立鋼製床で想定する仕様の $1 / 4$ 縮小を イメージして設定している。

鋼板は、実大実験では SS400 相当材、模型実験では SPCC 相当 材を用いている。上下面材と芯材の接合にはドリルねじを用い、実 大試験体では呼び径 $6 \mathrm{~mm}$ 、呼び長さ $35 \mathrm{~mm}$ のものを、模型試験体 では呼び径 $3.5 \mathrm{~mm}$ 、呼び長さ $16 \mathrm{~mm}$ のものを用いる。図 6 に、ね じ接合の様子を示す。また、芯材は、実大、模型試験体ともにおい て鋼板をプレスで曲げ加工して製作している。図 7 に、曲げ加工後 の芯材の例を示す。芯材の平面寸法が試験体の寸法に満たない場合 は、芯材のフランジ部分を重ね、前述のドリルねじを用いてフラン ジ 1 枚、および芯材 2 枚の鋼板を貫通して接合し、一体化させる。 模型試験体の残響室への設置方法も、実大実験と同様とする。図 8 に、2 辺支持と 4 辺支持のそれぞれにおける試験体の設置イメー ジを示す。 2 辺支持の場合には、残響室の開口部 (実大寸法で幅 1,020 ×長さ $770 \mathrm{~mm}$ ）の幅方向中央部に、床試験体の幅に相当する辺を、 厚さ $2.5 \mathrm{~mm}$ のゴムを介して設置する。また、床試験体の両脇に、 開口部塞ぎ用の厚さ $38 \mathrm{~mm}$ 、幅 $308 \mathrm{~mm}$ の鉄筋コンクリートの蓋を 1 体ずつ設置し（図 8)、試験体の四周と残響室の隙間、および蓋と 
表 3 床試験体の一覧

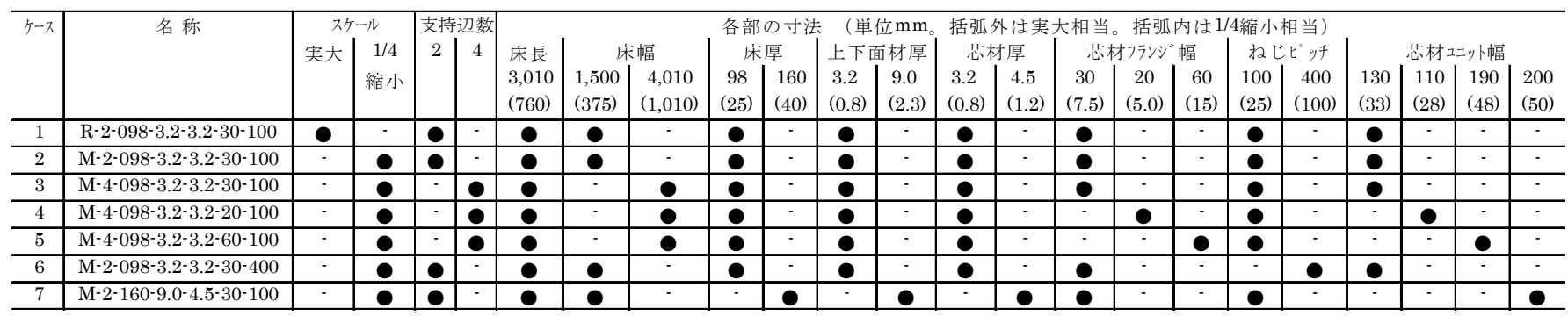

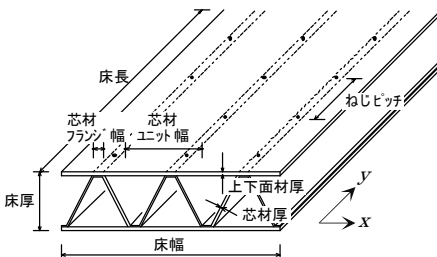

図 5 試験体各部の寸法の定義

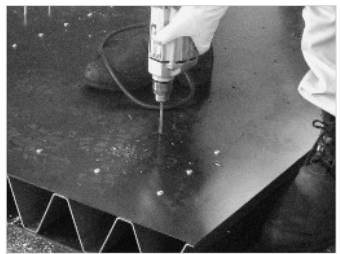

図 6 ねじ接合の様子

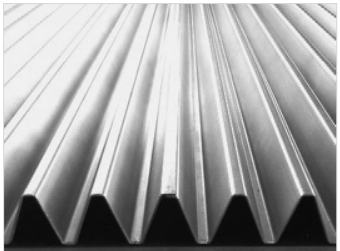

図 7 加工後の芯材の例
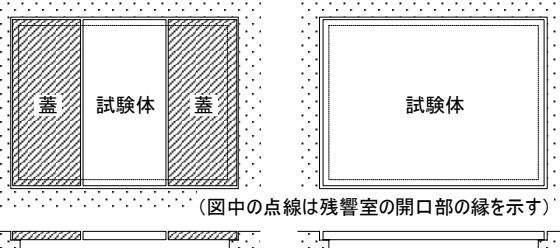

図 8 試験体の設置方法 (左:2 辺,右:4 辺支持)
残響室の隙間のそれぞれ $5 \mathrm{~mm}$ に油粘土を充填している。4 辺支持 の場合には、残響室の開口部に 4 辺支持の場合と同厚のゴムを介し て試験体を載せ掛け、試験体四周と残響室の隙間 $5 \mathrm{~mm}$ に油粘土を 充填する。実大実験の場合には前記寸法を 4 倍して対応している。 なお、床試験体の幅方向の端部には、床試験体の運搬や残響室への 設置しやすさを鑑み、試験体の幅方向の端部の鉛直面が平面となる ように、 C 形加工した芯材と同厚の鋼板をそのウェブ面が試験体幅 方向端部の鉛直面となるように設置している。

\section{4. 実験結果と考察}

\section{1. 重量床衝撃音}

図 9(a)〜(e)に、7 種類の試験体の重量床衝撃音の計測結果を示す。 各図はそれぞれ、(a)は実大と模型の比較、(b)は支持辺数と試験体幅 の影響、(c)は芯材フランジ幅の影響、(d)は秝じピッチの影響、(e) は床厚、上下面材厚などの影響に注目して整理している。各図の縦 軸は音圧レベル、横軸は $1 / 3$ オクターブバンドまたはオクターブバ ンド中心周波数を示す。模型実験の結果については、3.1.の模型則 比に従い、横軸は計測值を $1 / 4$ 倍し、縦軸は同じく模型則比に従っ て等倍して、かつ 3.3.の方針に従い、衝撃力の差分に応じて音圧レ ベルを補正した值を示す。

\section{(a) 実大実験と模型実験の比較}

図 9(a)の横軸がオクターブバンド中心周波数の結果から、3.3.で 示寸補正を行わないと、模型実験の結果は実大実験と比較して +5.0 〜+15.3dB 程度の大きさ差異を有することがわかる。これに対し、 補正を行うことにより、 $500 \mathrm{~Hz}$ 帯域以下においては、差異は L 值の 1 ランク相当に近づき、 $-5.2 \sim+7.0 \mathrm{~dB}$ 程度の範囲にとどまることが わかる。これにより、模型実験の結果を実大実験の結果に近づける という視点で、3.3.の補正の効果が得られていると考える。

また、同図の実大実験の結果から、乾式組立鋼製床の遮音性は、 JIS A 1419-2 の附属書 1 を参考に、計測結果が等級曲線を最大 $2 \mathrm{~dB}$ まで上回ることを許容した值として評価すると、 $63 \mathrm{~Hz}$ 帯域で L-5 55 となるのに対し、 $500 \mathrm{~Hz}$ 帯域では L-60 となっている。乾式組立鋼 製床において、一般的な鉄筋コンクリート床とは異なり、 $63 \mathrm{~Hz}$ 帯
域ではなく $500 \mathrm{~Hz}$ 帯域が L 数の決定周波数となる傾向があること については、上下面材の局所的な振動が遮音性に影響を及ぼしてい ると考えている。本内容については、次々節 4.3.で考察する。なお、 上記の遮音性の評価結果は、残響室の開口に床のみを構築して評価 した結果であり、実際の建築物においては梁や壁、床下空間の影響 を含めて評価する必要があることを考えると、絶対值としての性能 は過大に評価されている可能性がある。

\section{(b) 支持辺数（試験体幅）の影響}

図 9(b)の横軸がオクターブバンド中心周波数の結果から、支持辺 数を 2 辺から 4 辺にしつつ、同時に試験体幅を 1,500 から $4,010 \mathrm{~mm}$ （実大相当の寸法）に変更することで、63 $500 \mathrm{~Hz}$ 帯域において $3.2 \sim 8.5 \mathrm{~dB}$ 程度遮音性が向上寸る傾向が見られる。このことから、 乾式組立鋼製床において、一定幅を有する床パネルを 2 辺支持で設 置し、かつ床パネル同士をその幅方向の端面において接合しない場 合よりも、床パネル同士をその幅方向の端面において適切な固定度 で接合し、複数の床パネル相当の幅を持つ床全体が 4 辺支持となる ように設置する場合の方が遮音性を向上できる可能性があるといえ る。なお、前記の音圧レベルの差異において、支持辺数の変更の影 響と試験体幅の変更の影響は分離できておらず、両者の影響の分離 は今後の課題としたい。

\section{(c) 芯材フランジ幅の影響}

図 9(c)の横軸が $1 / 3$ オクターブバンドおよびオクターブバンド中 心周波数の結果から、 $32 \mathrm{~Hz}$ や $63 \mathrm{~Hz}$ 帯域といった低周波数帯域に おいては、芯材のフランジ幅を $60 、 30$ 、および $20 \mathrm{~mm}$ （実大相当 の寸法）と小さくするほど、音圧レベルも小さくなる傾向があるこ とがわかる。例えば、横軸がオクターブバンド中心周波数の結果で は、 $63 \mathrm{~Hz}$ 帯域において、芯材のフランジ幅が $20 \mathrm{~mm}$ と小さい場合 には、同 $60 \mathrm{~mm}$ と大きい場合と比較して $4.2 \mathrm{~dB}$ 程度遮音性が改善 されていることがわかる。これは、2.で述べたように、芯材に波板 を用いる乾式組立鋼製床においては、床断面内に上下面材と芯材に よるトラスが形成されると考えているが、芯材のフランジ幅が小さ いほどこの効果が高まり床の曲げ剛性が向上する傾向があることか ら、特に床全体の振動が遮音性に影響を及ぼすような低周波数領域 


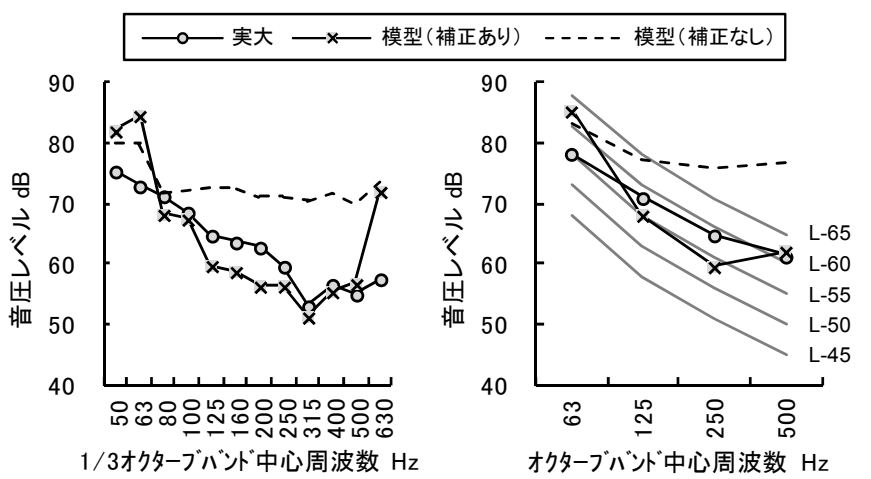

(a) 実大と模型の比較（ケース 1、2）

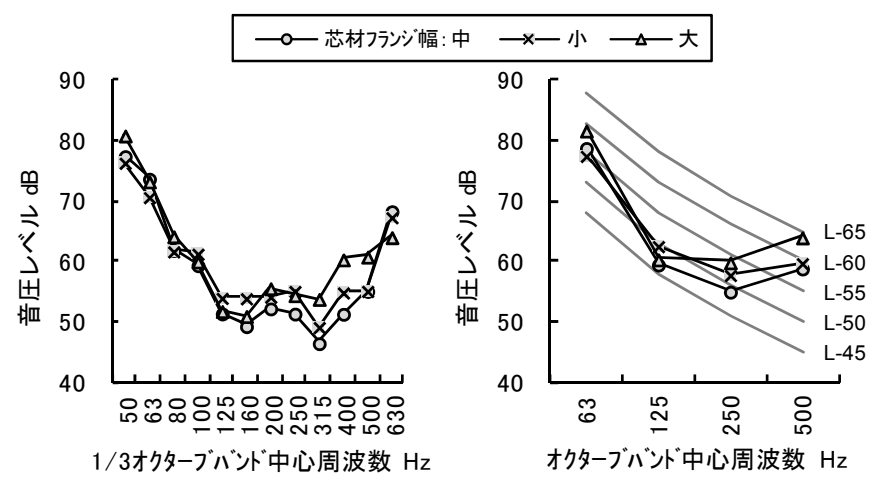

(c) 芯材フランジ幅の影響（ケース 3、4、5）

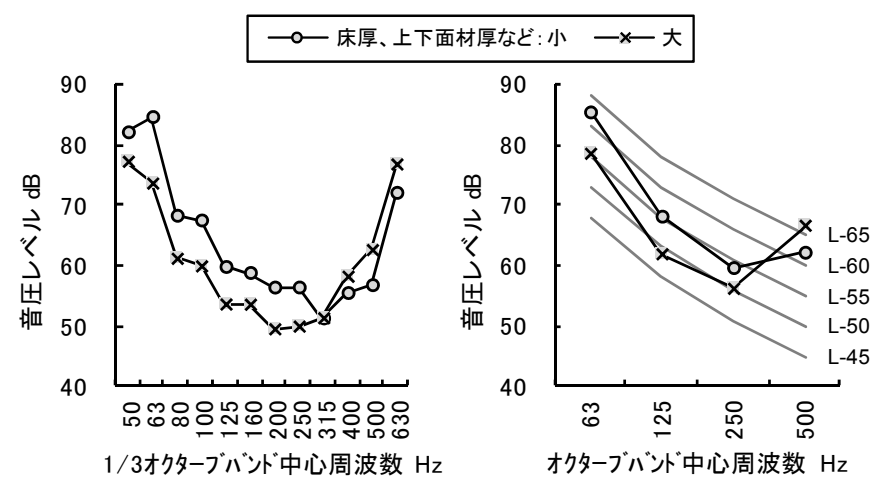

(e) 床厚、上下面材厚などの影響（ケース 2、7）

図 9 重量床衝撃音の計測結果

において、芯材のフランジ幅が小さいほど遮音性を向上できる可能 性があると考えている。本内容については、次節 4.2.で考察する。

(d) ねじピッチの影響

図 9(d)から、今回の模型実験の結果においては、ねじピッチを 100 から $400 \mathrm{~mm}$ （実大相当の寸法）まで大きくしても、変更前後での 音圧の差異はほとんど見られず、㸚じピッチが遮音性に及ぼす影響 は小さいことがわかる。これは、文献 16)や 18)などを参照すると、 一般的なドリル衫じ接合部は、补じ径や被接合部材の材質や板厚に 依存するばね定数や耐力を有し、その荷重変形関係はマルチリニア として表現されるが、本論の模型実験の加振力レベルでは、ねじに 作用する力がそれほど大きくならず、ピッチを $400 \mathrm{~mm}$ まで大きく する場合でも、 $100 \mathrm{~mm}$ の場合と同様のばね定数を有する範囲で応 答したためと推察している。また、本論の模型実験においては、手 配可能なものとして、呼び径 3.5 のドリルねじを用いており、実大

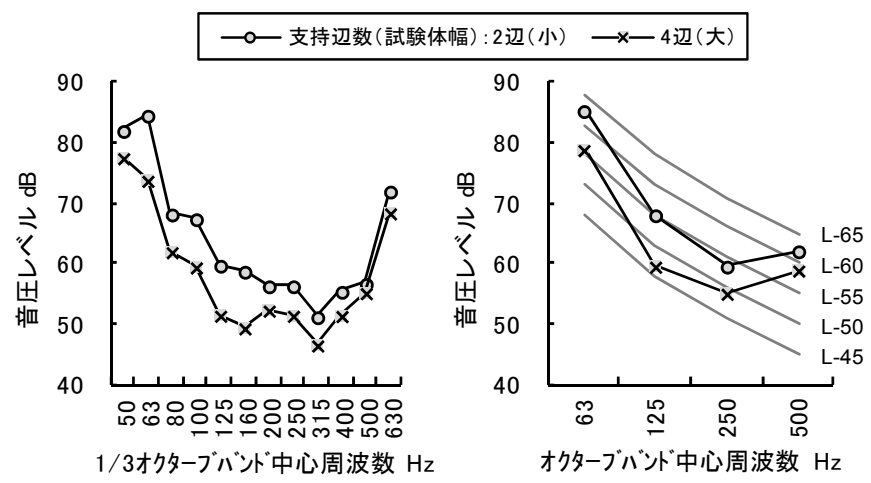

(b) 支持辺数（試験体幅）の影響（ケース2、3）

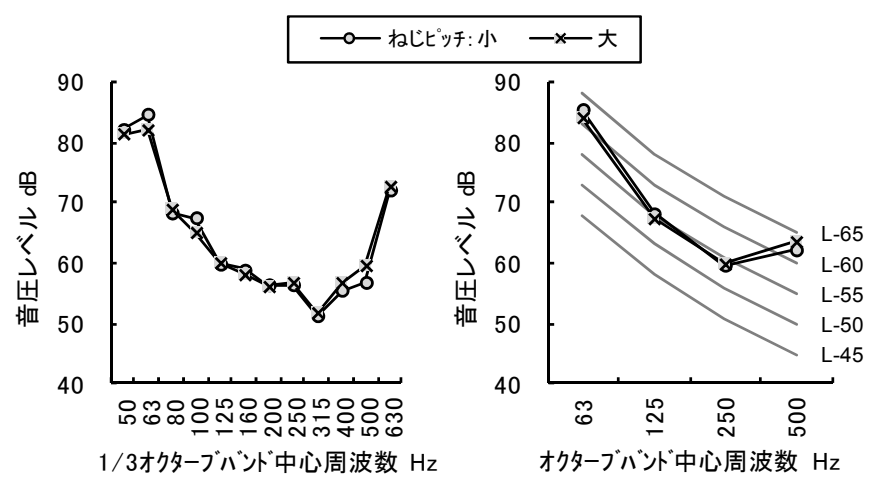

(d) ねじピッチの影響（ケース 2、6）

実験の $1 / 2$ 程度にとどまるものであるため、実大実験においては本 模型実験の傾向とは異なる結果が得られる可能性もあり、実大寸法 における遮音性の視点からのねじピッチの策定には別途検討が必要 と考える。

(e) 床厚、上下面材厚などの影響

図 9(e)から、床厚を 98 から $160 \mathrm{~mm}$ 、上下面材厚を 3.2 から $9.0 \mathrm{~mm}$ 、 芯材厚を 3.2 から $4.5 \mathrm{~mm}$ 一と拡大したことにより（実大相当での 寸法)、63 250Hz 帯域において 3.4 6.8dB 程度の遮音性の向上効 果が得られている。これは、床の質量と曲げ剛性が増加した影響と 考えられる。一方、床厚 $160 \mathrm{~mm}$ の試験体においても、床厚 $98 \mathrm{~mm}$ の試験体と同様に、 $500 \mathrm{~Hz}$ 帯域の音圧レベルが大きくなる傾向が見 られる。本傾向については、床厚 $98 \mathrm{~mm}$ の試験体とあわせて 次々節 4.3 で考察する。

\section{2. 弱軸回りの曲げ剛性の影響}

芯材に波形の鋼板を用いる鋼製床においては、床断面内に上下面 材と芯材によるトラスが形成され、図 1 に示す $\mathrm{x}$ 軸回りの曲げに対 してだけでなく、y 軸回りの曲げに対してもサンドイッチパネルの 効果の発現が期待できる。これにより、y 軸回りの曲げに対しては、 上下面材と芯材の 3 枚の板からなる重齐板としてよりも大きな剛性 が得られる一方、 $\mathrm{x}$ 軸回りほど大きな值は得られないと考えられる。 結果として、芯材を波形部材とする鋼製床は、ボイドスラブなどと 同様に 25) 29) なと、曲げ剛性に方向性を有する板として挙動すると推 察する。そこで本節では、図 1 に示す $\mathrm{x}$ 軸回りを強軸回り、y 軸回 りを弱軸回りと称し、乾式組立鋼製床の質量や曲げ岡性といった物 理量のうち、特に弱軸回りの曲げ剛性が重量床衝撃音に及ぼす影響 についての考察を行う。 
表 4 芯材フランジ幅を変化させる 3 種の試験体の性能一覧

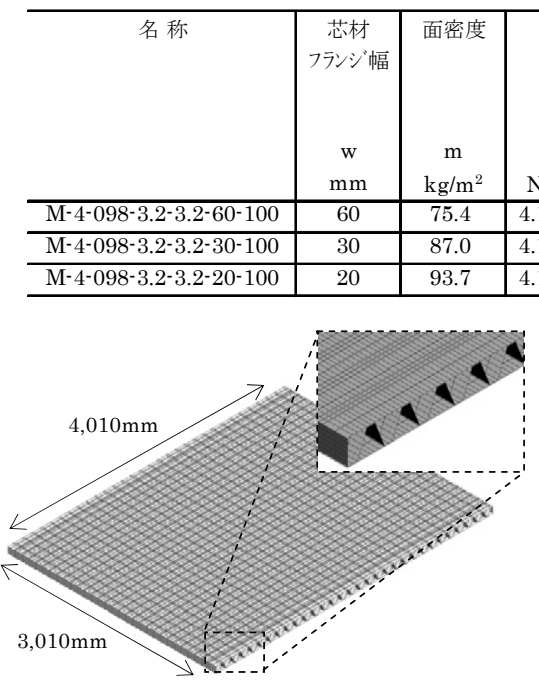

図 103 点曲げに用いる解析モデル (芯材フランジ幅 $30 \mathrm{~mm}$ のもの)
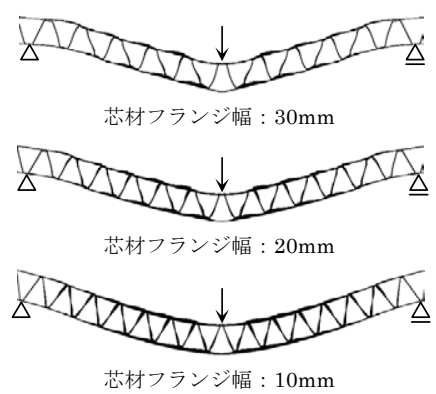

図 113 点曲げ時の変形の様子

\begin{tabular}{|c|c|c|c|c|c|}
\hline & & 基本价 & ンダンス & & \\
\hline & & $\begin{array}{l}\text { 強軸 } \\
\text { とも }\end{array}$ & & $\begin{array}{l}\text { 弱㜞 } \\
\text { のみ }\end{array}$ & \\
\hline $\begin{array}{c}Z_{x} \\
\mathrm{~kg} / \mathrm{s}\end{array}$ & $\begin{array}{l}\mathrm{L}_{\mathrm{zx}} \\
\mathrm{dB}\end{array}$ & $\begin{array}{c}Z_{\mathrm{xy}} \\
\mathrm{kg} / \mathrm{s}\end{array}$ & $\begin{array}{l}\mathrm{L}_{\mathrm{zxy}} \\
\mathrm{kg} / \mathrm{s}\end{array}$ & $\begin{array}{l}Z_{\mathrm{xy}} \\
\mathrm{kg} / \mathrm{s}\end{array}$ & $\begin{array}{l}\mathrm{L}_{\mathrm{zxy}} \\
\mathrm{kg} / \mathrm{s}\end{array}$ \\
\hline $1.4 \mathrm{E}+05$ & 103.1 & $8.0 \mathrm{E}+04$ & 98.1 & $4.5 \mathrm{E}+04$ & 93.1 \\
\hline $1.5 \mathrm{E}+05$ & 103.7 & $1.0 \mathrm{E}+05$ & 100.0 & $6.5 \mathrm{E}+04$ & 96.3 \\
\hline $1.6 \mathrm{E}+05$ & 104.0 & $1.2 \mathrm{E}+05$ & 101.5 & $9.0 \mathrm{E}+04$ & 99.1 \\
\hline
\end{tabular}

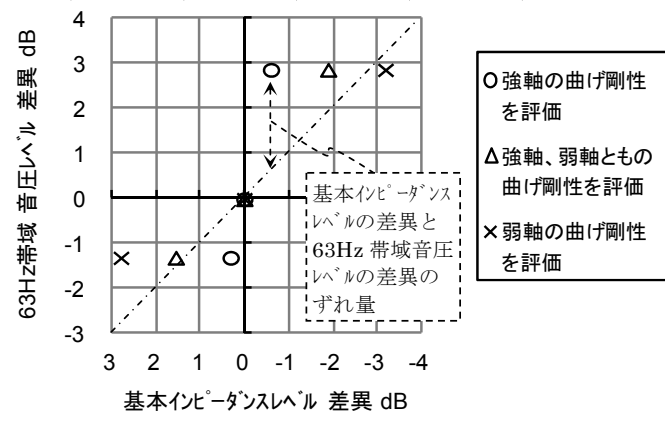

図 12 基本インピーダンスと $63 \mathrm{~Hz}$ 帯域音圧の比較

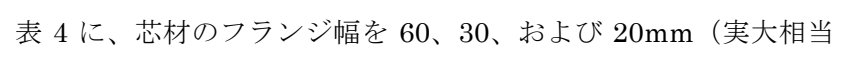
の寸法）と変化させた場合の試験体（表 1 のケース 3〜5）の単位面 積当たりの質量、単位幅当たりの曲げ剛性、および基本インピーダ ンスを示す。同表において、面密度は上下面材と芯材を評価して計 算している。曲げ剛性は、上下面材と芯材がドリルねじの位置で剛 に接合されていると想定した上で、強軸回りについては上下面材と 芯材の断面形状から計算し、弱軸回りについては図 10 に示す 3 点 曲げの数值解析を行い、スパン中央部の荷重変形関係から、せん断 変形を無視した等価な曲げ剛性として計算している。図 10 の数值 解析において、汎用プログラムの MSC.Nastran を用い、解析種別 は材料線形、かつ幾何学的線形とし、鋼材のヤング係数 $E=205,000$ $\mathrm{N} / \mathrm{mm}^{2}$ 、ポワソン比 $v=0.3$ としている。上下面材と芯材は、その 板厚中心線上にシェル要素を用いてモデル化し、㸚じ接合部は、面 材と芯材の被接合位置の節点を、座標の差異を考慮する剛体要素で その両端の 6 自由度を固定する条件で結合してモデル化している。 また、基本インピーダンスは、文献 25)、26)、および 30)などを参 考に、強軸の曲げ岡性のみを評価する場合と、下記の式(6)を用いて 強軸と弱軸ともの曲げ剛性を評価する場合、および弱軸回りの曲げ 剛性のみを評価する場合の 3 種類を示す。基本インピーダンスレベ ルは基準值を $1 \mathrm{~kg} / \mathrm{s}$ として計算している。

$$
Z_{x y}=8 \sqrt{m \cdot \sqrt{E I_{x} \cdot E I_{y}}}
$$

ここで、 $Z_{x y}$ は強軸と弱軸の曲げ剛性をともに評価する基本インピー ダンス、 $m$ は面密度、 $E I_{x}$ は強軸回りの曲げ剛性、 $E I_{y}$ は弱軸回りの 曲げ剛性を示す。

表 4 から、芯材のフランジ幅を小さくすると、強軸回りの曲げ剛 性の変化は小さい一方で、弱軸回りの曲代剛性は大きくなる傾向が 見られることがわかる。芯材のフランジ幅が $60 \mathrm{~mm}$ の場合は強軸回 りの剛性に対して $1 / 9.9$ 程度にとどまるのに対し、同 $20 \mathrm{~mm}$ では 1/3.3 程度まで大きくなっている。この理由について、断面の変形を 参照して考察する。図 11 に、芯材のフランジ幅を $30 、 20$ 、および $10 \mathrm{~mm}$ と変化させた場合の 3 点曲げ時の床断面の変形の様子を示す。
同図から、芯材のフランジ幅を小さくすると、床断面の変形がせん 断変形状から曲げ変形状に変化していることがわかる。これは、上 下面と芯材で構成される床断面内のトラスにおいて、芯材のフラン ジ幅が大きいとトラスの個材の交点のずれも大きくなり、個材に大 きな曲げ変形が生じてトラスの効果が得られにくくなるのに対し、 芯材のフランジ幅を小さくすることでこの現象が緩和されているた めと推察する。

図 12 に、芯材のフランジ幅を変化させた 3 種類の試験体につい て、表 4 で計算した基本インピーダンスレベルと、実大相当で $63 \mathrm{~Hz}$ 帯域の音圧レベルの実験結果を比較して示す。図の縦軸は芯材のフ ランジが幅 $30 \mathrm{~mm}$ の試験体を基準とした $63 \mathrm{~Hz}$ 帯域の音圧レベルの 相対值、横軸は同様に $30 \mathrm{~mm}$ の試験体を基準とした基本インピーダ ンスのレベルの相対值を示す。図中、強軸回りの曲げ剛性のみを評 価する場合、強軸、弱軸ともの曲げ剛性を評価する場合、および弱 軸回りの曲げ剛性を評価する場合の 3 種類を記載している。

図 12 から、強軸回りの曲げ剛性のみを評価する場合よりも、強 軸、弱軸ともの曲げ剛性を評価する場合、または弱軸回りの曲げの 剛性のみを評価する場合の方が、基本インピーダンスの相対值と $63 \mathrm{~Hz}$ 帯域の音圧レベルの差異が整合する傾向があることがわかる。 これは、芯材のフランジ幅を変化させる場合、強軸回りの曲げ剛性 の変化は小さいが、弱軸回りの曲げ剛性の変化は大きいことによっ ており、平板と波板からなる乾式組立鋼製床の遮音性の評価におい ては、芯材の形状によっては、強軸回りの曲げ剛性だけでなく、弱 軸回りの曲げ剛性の影響を適切に評価寸る必要があるといえる。な お、図 12 に点線で示す両者の差異のずれ量について、フランジ幅 が $20 \mathrm{~mm}$ の試験体と同 $30 \mathrm{~mm}$ の試験体のずれ量の絶対值と、同 $20 \mathrm{~mm}$ と同 $10 \mathrm{~mm}$ の試験体のずれ量の絶対值の合計を計算すると、 強軸回りの曲げ剛性を評価する場合は $3.3 \mathrm{~dB}$ 、強軸、弱軸ともの曲 げ剛性を評価する場合は $1.2 \mathrm{~dB}$ 、弱軸回りともの曲げ剛性を評価す る場合は $1.8 \mathrm{~dB}$ となり、本実験結果においては、強軸、弱軸ともの 曲げ剛性を評価する場合において、その他の場合よりも、基本イン ピーダンスの相対值と $63 \mathrm{~Hz}$ 帯域の音圧レベルの差異が整合する傾 
向がある。

また、図 12 から、弱軸回りの曲げ剛性のみを評価する場合、基 本インピーダンスの差異の絶対值以上には $63 \mathrm{~Hz}$ 帯域の音圧レベル の差異の絶対值は変化しないことがわかる。このことから、弱軸回 りの曲げ剛性を評価することで乾式組立鋼製床の遮音性を安全側に 評価できる可能性があると考えている。

\section{3. 下面材の振動の影響}

本論の乾式組立鋼製床においては、芯材を波形の部材としている ことにより、残響室に接する下面材は、床の幅方向に一定の間隔で 離散的に支持されている。これにより、ボイドスラブでも見られる ように ${ }^{31)}$ 、床全体の振動とは別に、下面材が部分的に振動すること が懸念される。そこで、本節では、固有值解析を用いる乾式組立鋼 製床の振動性状の評価を試み、その影響について考察する。

図 13 に振動固有值解析のモデルを示す。解析対象は表 3 中のケ ース 1 の実大実験とする。モデルの作成条件と解析プログラムは 4.2 と同様とし、鋼材の比重 $\rho=7.85$ とする。支持条件は、残響室実験 において、長さ $3,010 \mathrm{~mm}$ の試験体がその両端 $145 \mathrm{~mm}$ ずつ載せ掛 けて設置されることを想定して、支持辺 2 辺間の距離が $2,720 \mathrm{~mm}$ の単純支持としている。

図 14 に振動固有值解析の結果として、床全体の 1 次振動モード、 面材が部分的に振動し始めるモード、および面材が幅方向に 11 分 割（芯材のフランジによる支持で分割される数に相当）されて振動 し始めるモードを示す。それぞれのモード次数は、 1 次、 77 次、 170 次であった。掲載していないモードとしては、全体の高次モードや、 モデルの周辺部で衫じ接合されていない面材や芯材が局所的に振動 するモードが見られた。図から、本論の乾式組立鋼製床を残響室に 設置した際の振動性状として、低次モードでは、支持部が節となり 床全体が振動するのに対して、モードが高次化するにつれて、床全 体の振動と上下面材と芯材の振動が連成するようになり、高次モー ドでは、床全体ではなく上下面材や芯材が単独で振動するような傾
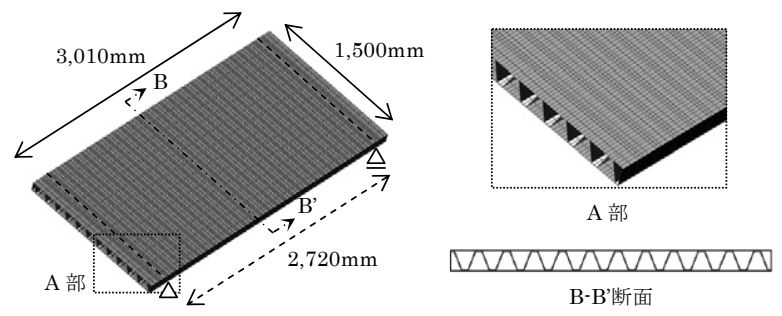

図 13 振動固有值解析のモデル

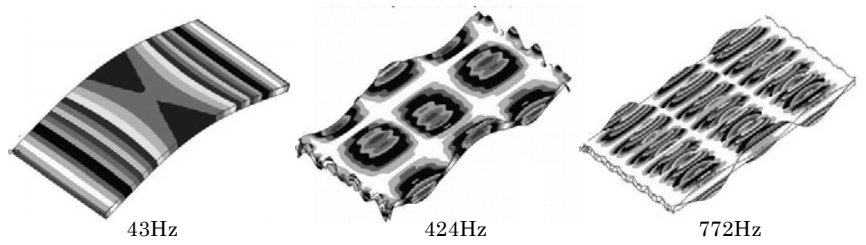

図 14 振動固有値解析の結果

表 5 短冊状に 4 辺支持される部分の寸法と振動数

\begin{tabular}{|c|c|c|c|c|c|c|c|}
\hline \multirow[t]{4}{*}{ 名称 } & \multicolumn{3}{|c|}{ 短冊状の部分の寸法 } & \multicolumn{4}{|c|}{ 振動モードと振動数 } \\
\hline & 厚さ & 幅 & 長さ & $\mathrm{m}, \mathrm{n}=1,1$ & $\mathrm{~m}, \mathrm{n}=1,2$ & $\mathrm{~m}, \mathrm{n}=1,3$ & $\mathrm{~m}, \mathrm{n}=2,1$ \\
\hline & $\mathrm{t}$ & b & 1 & $f$ & $\mathrm{f}$ & $\mathrm{f}$ & $\mathrm{f}$ \\
\hline & $\mathrm{mm}$ & $\mathrm{mm}$ & $\mathrm{mm}$ & $\mathrm{Hz}$ & $\mathrm{Hz}$ & $\mathrm{Hz}$ & $\mathrm{Hz}$ \\
\hline $\mathrm{R}-2-098^{-} 3.2-3.2-30-100$ & 3.2 & 130 & 3,010 & 461 & 463 & 468 & 1,841 \\
\hline $\mathrm{R}-2-160-9.0-4.5-30-100$ & 9.0 & 200 & 3,010 & 549 & 556 & 568 & 2,189 \\
\hline
\end{tabular}

向がみられることがわかる。

この傾向を踏まえ、下面材について、その長さ方向の端部、およ び芯材との接合部で囲われる短冊状の部分が、4 辺単純支持される と想定した場合の振動数を、式(7)によって計算した結果を表 5 に示 す。表中には、表 3 のケース 1 、およびケース 7 に相当するものを 実大相当の寸法として想定した場合を示している。

$$
f_{m n}=(\pi / 2) \cdot \sqrt{\left(E \cdot t^{2}\right) /\left(12 \cdot \rho \cdot\left(1-v^{2}\right)\right)} \cdot\left[(m / a)^{2}+(n / b)^{2}\right]
$$

ここで、 $E$ は鋼材のヤング係数、 $t$ は上下面材厚、 $\rho$ は比重、岒ポ ワソン比、 $a 、 b$ は上下面材の幅と長さ、 $m 、 n$ は幅と長さ方向のモ ードの次数を示す。

表 5 から、短冊状に 4 辺支持される部分の振動数は 2 種類の試験 体でそれぞれ $461 \mathrm{~Hz} 、 549 \mathrm{~Hz}$ となっていることがわかる。これは、 図 14 に示寸固有值解析結果で、下面材の部分振動が生じ始める振 動数が $424 \mathrm{~Hz}$ であったことと整合する結果と考えている。これらの 振動数がオクターブバンドで $500 \mathrm{~Hz}$ 帯域の範囲内となっているこ とから、4.1.(a)や(e)で見られた $500 \mathrm{~Hz}$ 帯域の音圧レベルが大きく なる傾向については、この下面材の部分的な振動が影響を及ぼして いると考察する。

乾式組立鋼製床の重量床衝撃音に対する遮断性がこの下面材の振 動により低下寸るのを避けるためには、この振動数を $500 \mathrm{~Hz}$ 帯域以 上、または天井板や仕上材が設置されるという前提で、それらの材 料による低減効果が期待できる程度の振動数以上となるように、下 面材の板厚や芯材のユニット幅などを調整するといった対応が必要 になると考える。

\section{5. まとめ}

本論では、鋼構造の長所の更なる促進を狙い、現場生産のコンク リート床に代わって適用可能な鋼製部材の将来的な具現化を目指し、 その端緒として、乾式組立床の重量床衝撃音の遮断性の評価に取り 組んだ。得られた知見を以下に示す。

1）乾式組立鋼製床の重量床衝撃音を、軟式 $\mathrm{A}$ 球を用いる $1 / 4$ 縮小 型実験で評価する場合には、軟式 A 球と標準重量衝撃源 (タイヤ) の衝撃力の差異に応じて模型実験の音圧レベルを補正することに より、実大実験の傾向に近い結果を得ることができる。

2）平板と波板からなる乾式組立鋼製床は、芯材の形状によっては、 曲げ剛性に関して方向性を有する板として評価される。弱軸方向 の曲げ岡性を向上することにより、乾式組立鋼製床の重量床衝撃 音が改善される傾向がみられる。芯材を波板とする場合、芯材の フランジ幅を小さくすることにより弱軸方向の曲げ剛性を向上す ることができる。

3）平板と波板からなる乾式組立鋼製床においては、一般的な鉄筋 コンクリート床とは異なり、 $63 \mathrm{~Hz}$ 帯域ではなく $500 \mathrm{~Hz}$ 帯域が L 数の決定周波数となる傾向がある。これは、下面材の部分的な振 動が影響を及ぼしていると考えられる。下面材の部分的な振動に より影響を受ける周波数の範囲は、芯材の支持線で囲われる短冊 状下面材の振動数を計算することにより想定できる。

\section{6. 今後の課題}

本論では、芯材に波形に加工した鋼板を用いる床についての重量 
床衝撃音の遮断性の評価を行った。今後は、芯材に波形以外の部材 を用いる床や、鋼材と他の部材を組み合わせる床の評価も行い、よ り遮音性が高く、より実現可能性の高い床断面の導出が課題と考え る。また、重量床衝撃音以外の環境性や、構造性、施工性などの評 価も行ってゆく必要があるといえる。

\section{参考文献}

1）日本鋼構造協会：性能別に考える $\mathrm{S}$ 造設計 構法・ディテール 選定マニ ユアル, エクスナレッジ, 2006

2）日本鋼構造協会：鋼構造建築物の床構工法, JSSC テクニカルレポート, 2009.9

3）金子裕一，岡本晴彦，大野定俊，柿沢忠弘：超軽量コンクリート床スラブ の開発, その 1 超軽量コンクリートの材料特性, 日本建築学会大会学術講 演梗概集, C-2, 構造 IV, pp.755-756, 1999.7

4）岡日出夫，五十嵐信哉，山田聖志，北東宏郎：軽量材料をコア材とするサ ンドイッチ構造床版, その 1 鋼/ALC パネル試験体と曲げ加力実験結果, 日本建築学会大会学術講演梗概集, C-1, 構造 III, pp.667-668, 2009.7

5）西村拓也，坂本真一，立石寧俊，椚隆：脱着可能なフル・プレキャストス ラブを適用した鉄骨架構の構造性能，日本建築学会構造系論文集，第 602 号, pp.233-241, 2006.4

6）聲高裕治：鋼構造骨組における床スラブの解体性を考慮した簡易免震床 構造システムの開発, その 11 層骨組の地震応答, 日本建築学会大会学術講 演梗概集, C-1, 構造 III, pp.901-902, 2009.7

7）小坂英之, 渡邊一弘, 森田隆司, 白石哲也：リュース対応型のフル $\mathrm{PCa}$ 床システムの開発，その 1 床システムの概要と曲げ実験，日本建築学会大 会学術講演梗概集, C-1, 構造 III, pp.669-670, 2007.7

8) D. Braun, S.J. Kennedy, D.J.L. Kennedy, D.E. Allen: Sandwich Plates System Risers for Stadia, SSRC Annual Stability Conference, Seattle, pp.461-479, 2002.4

9）金箱温春, 佐久間拓：多様な要求に応えるスラブ設計入門/ デッキプレ 一トと構造用合板のハイブリッド床，建築技術, pp.180-181, 2001.5

10）末永晋一，牧野充記，持田哲雄：曲げ鋼板とフランジコンクリートで構 成されたプレキャスト中空スラブの長期たわみ性状, その 1 長期載荷実験 結果, 日本建築学会大会学術講演梗概集, C-2, 構造 IV, pp.449-450, 2005.7

11）梅沢良三：多様な要求に応えるスラブ設計入門/サンドイッチ折版構造 の鉄骨スラブ, 建築技術, pp.182-187, 2001.5

12）富岡義人，河野守，石原直，渡邊力，大隅康令，五十嵐規矩夫：薄板鉄鋼 材料を用いた鋼構造建築物の可能性の探求と開発，その 1 鋼薄板を利用し た構造形式の構想と研究の全体像, 日本建築学会大会学術講演梗概集, A-1, 材料施工, pp.971-972, 2007.7

13）日本建築学会: 床の性能評価方法概要集, 2004.4

14）日本建築学会：鉄筋コンクリート構造計算基準, 1999

15）合成スラブ工業会：設計・施工マニュアル, 2005.3

16）日本鉄鋼連盟：薄板軽量形鋼造建築部の設計の手引き, 2004.6

17）唐津敏一, 清水秀夫, 岡田久志, 渡邊力, 河合良道, 上岡優, 大和田哲: 繰り返しせん断試験 ドリルねじ接合の鉄骨造への適用に関する研究, そ の 5 接合要素, 日本建築学会大会学術講演梗概集, C-1, 構造 III, pp.591-592, 2005.7

18）半谷公司，菅野良一，河合良道：薄鋼板溝形鋼と構造用合板からなる合 成パネルの曲げ耐力, その 3 有限要素解析, 日本建築学会大会学術講演梗 概集, C-1, 構造 III, pp.625-626, 1997.7

19）荘美知子, 木村翔, 鈴木久恵, 梶裕佳子：集合住宅の住環境全般と音環 境に対する居住者評価の分析, 日本建築学会計画系論文集, 第 493 号, pp.9-15, 1997.3

20）福島寛和，井上勝夫，安岡正人：集合住宅の界壁 - 界床の遮音性能表示 方法(案)の主要検討結果の報告 住宅性能表示制度(案)の概要紹介, 日本建 築学会大会学術講演梗概集, D-1, 環境工学 I, pp.167-170, 1998.9

21）日本建築学会：建物の遮音設計資料, 1988.8

22）江守一郎：模型実験の理論と応用，技報堂出版, 1973

23）木村剛, 石井和俊，泉潤一，福島寛和，井上勝夫：枠組壁工法共同住宅 の重量床衝撃音模型実験, その 2 種々の床仕様に関する検討結果, 日本建 築学会大会学術講演梗概集, D, 環境工学, pp.1573-1574, 1994.7

24）中安誠明, 半谷公司, 高橋大武: $1 / 4$ 縮小模型を用いた $\mathrm{RC}$ 床の重量衝撃 音評価, 日本建築学会大会学術講演梗概集, 環境工学 I, pp.307-308,
2012.9

25）渡辺大助，井上勝夫，鈴木俊男：異方性スラブの振動特性に関する基礎 的検討, 日本建築学会環境系論文集, 第 77 巻, 680 号, pp761-769, 2012.10 26）鈴木俊男，井上勝夫：異方性スラブの振動特性に関する検討 その 3 基 本インピーダンスの算定, 日本建築学会大会学術講演梗概集, D-1, 環境工 学 I, pp161-162, 2010.7

27）新田貴太男，椴木浩行，坂田憲彦，坂本康一郎，松本慎也，藤谷義信：ボ イドスラブの振動特性に関する研究 - 実構造物における間仕切壁の振動特 性一の影響-，日本建築学会技術報告集，第 16 号, pp.101-104, 2002.12

28）橋本典久：固有值解析によるボイドスラブの床衝撃音遮断性能評価 面 内面外変位連成型有限要素法によるボイドスラブの床衝撃音解析 その 1 , 日本建築学会計画系論文集，第 556 号, pp.9-15, 2002.6

29) N.E.S. Albano: Low frequency impact sound transmission through timber-joisted floors, 15th International Congress on Sound and Vibration, pp.1227-1234, 2008.7

30）日本建築学会：建物の床衝撃音防止設計, 2009.11

31）井上勝夫，木村翔，豊田雅士：ボイドスラブを対象とした重量床衝撃音 レベルの計算法の検討, 日本建築学会大会学術講演梗概集, D-1, 環境工学 I, pp.187-190, 1998.7 


\title{
EVALUATION OF IMPACT SOUND INSULATION PERFORMANCE \\ OF DRYLY BUILT-UP STEEL FLOOR \\ MADE OF FLAT AND CORRUGATED PLATES
}

\author{
Nariaki NAKAYASU ${ }^{* 1}$, Koji HANYA*2, Ryoichi KANNO*3 \\ and Daiji TAKAHASHI* \\ ${ }^{* 1}$ Researcher, Nippon Steel \& Sumitomo Metal Corporation, M. Eng. \\ * 2 Senior Researcher, Nippon Steel \& Sumitomo Metal Corporation, Dr. Eng. \\ * 3 Fellow, Nippon Steel \& Sumitomo Metal Corporation, Ph. D. \\ ${ }^{*}$ Prof., Dept. of Architecture and Architectural Engineering, Kyoto University, Dr. Eng.
}

Steel structures have merits such as light weight and short period of construction. Aiming at realization of such a steel floor, scaled model test and full-scale test have been carried out in order to evaluate the impact sound insulation performance of steel floor using flat and corrugated plates. Test results indicate, 1) the correction of sound level of steel floor in scale model test is effective by following the difference of impact force characteristics between scaled model test and full-scale test, 2) steel floor made of flat and corrugate plates tends to have anisotropy in bending stiffness and sound insulation performance of the floor can be improved by increasing the bending stiffness around weak axis, for example by narrowing the width of flange of corrugated steel plate, and 3) local vibration of lower flat plate may worsen the insulation performance of steel floor but its frequency can be designed in the higher range so that the decreasing of sound level is relatively easier.

（2014年 5 月 4 日原稿受理, 2014年 9 月10日採用決定） 